Rok XV (2020) | 2 (30)|S. 209-220

https://doi.org/10.12797/LV.15.2020.30.16

Alicja Pihan-Kijasowa •

Uniwersytet im. Adama Mickiewicza, Poznań

apki@amu.edu.pl

\title{
POCZĄTKI JĘZYKOZNAWSTWA POLONISTYCZNEGO NA UNIWERSYTECIE POZNAŃSKIM
}

Słowa klucze: historia nauki, Uniwersytet Poznański, językoznawstwo polonistyczne, ludzie nauki, obszary badawcze

Keywords: history of science, Poznań University, Polish language studies, scholars, fields of study

Wraz z odzyskaniem przez Polskę niepodległości w 1918 r. powróciła w Poznaniu myśl o założeniu w mieście polskiego uniwersytetu. Przy działającym od 1857 r. Poznańskim Towarzystwie Przyjaciół Nauk ukonstytuowała się Komisja Organizacyjna Uniwersytetu Polskiego w Poznaniu, w której skład weszli: dr Heliodor Święcicki, dr hab. Józef Kostrzewski, dr hab. Michał Sobeski i ks. dr Stanisław Kozierowski. Już 7 maja 1919 r. nowo powstały uniwersytet zainaugurował swoją działalność. W ciągu pierwszego roku pracę rozpoczęły cztery wydziały: wpierw Wydział Prawa i Nauk Ekonomiczno-Politycznych oraz Wydział Filozoficzny, następnie Wydział Rolniczo-Leśny i Wydział Lekarski. Schemat organizacyjny i skład osobowy (kierowników katedr) dla uniwersytetu w Poznaniu opracował Józef Kallenbach, profesor historii literatury polskiej na Uniwersytecie Warszawskim, pracujący nad tą kwestią na zlecenie Komisji Stabilizacyjnej powołanej przez Ministerstwo Wyznań Religijnych i Oświecenia Publicznego (Maciejewski 2018: 47; Łukomski 2019). Natomiast ze strony uniwersytetu o pozyskanie kadry zabiegał głównie M. Sobeski. Badania lingwistyczne i literaturoznawcze oraz studia polonistyczne odbywały się na Wydziale Filozoficznym, zbudowanym z 21 katedr, w tym 13 Sekcji Humanistycznych (Łukomski 2019). Kallenbach zaproponował powołanie dwóch katedr literatury pol- 
skiej (profesorów Tadeusza Grabowskiego i Juliusza Kleinera lub Konstantego Wojciechowskiego), katedry języka polskiego, którą miał kierować Stanisław Dobrzycki, katedry filologii słowiańskiej Tadeusza Lehra-Spławińskiego i katedry językoznawstwa indoeuropejskiego Mikołaja Rudnickiego (Maciejewski 2018: 47). Ostatecznie jednak Dobrzycki objął katedrę historii literatury polskiej, a katedra języka polskiego powstała nieco później, w 1922 r.; powierzono ją Edwardowi Klichowi (Kaniewska 2018: 13; Maciejewski 2018: 56). W tym też 1922 r. z Poznania do Lwowa odszedł Lehr-Spławiński, natomiast ze Lwowa do Poznania przybył Henryk Ułaszyn. Jak ocenia Stanisław Urbańczyk: „Uniwersytet Poznański otrzymał młodą profesorską obsadę [...]. Wszyscy oni byli już dobrze znani w nauce" (Urbańczyk 1993: 214). Byli to przybysze z zewnątrz.

[...] w ciemnym półwieczu historii polskiej kultury w Wielkopolsce, w latach 18701918, warunki stworzone przez zaborcę wyludniły tę część kraju z twórczych indywidualności i dlatego polskie środowisko naukowe i nauczycielskie było tu bardzo szczupłe, a w zakresie dyscyplin polonistycznych w ogóle go nie było (Maciejewski 2018: 38).

Pierwsi językoznawcy na Uniwersytecie Poznańskim (UP): Rudnicki, Lehr-Spławiński, a także Dobrzycki, którego badania obejmowały nie tylko historię literatury polskiej, ale też historię języka i dialektologię, to wychowankowie Uniwersytetu Jagiellońskiego, podobnie jak nieco później przybyły do Poznania Klich. Natomiast Ułaszyn studia odbył i karierę naukową rozpoczął na uniwersytecie we Lwowie. Dopiero w kilka lat później do grona tego dołączają absolwenci UP, jak: Adam Tomaszewski, ks. Piotr Gołąb czy Władysław Pniewski, którzy co prawda nie byli z uniwersytetem związani etatowo, ale współpracowali z nim naukowo. Jedynie Stanisław Kozierowski, współtwórca uczelni, ksiądz, genealog, heraldyk, językoznawca, nie odbył studiów polonistycznych i w zakresie lingwistyki był samoukiem.

W pierwszych latach istnienia w Poznaniu uniwersytetu (1919-1922) dla językoznawstwa polonistycznego zabrakło struktury organizacyjnej. Gdy przybyły z Krakowa Dobrzycki zdecydował się objąć katedrę literatury polskiej, a nie języka polskiego, nie było w młodej uczelni profesora, który taką katedrą mógłby kierować. To w sposób oczywisty nie sprzyjało rozwojowi tej dyscypliny. Nie oznacza to jednak, że badania językoznawcze obejmujące polski obszar językowy w aspekcie współczesnym i historycznym nie były prowadzone. Rudnicki i Lehr-Spławiński, pierwsze pokolenie poznańskich lingwistów, choć ich zainteresowania naukowe wykraczały poza obręb polonistyczny (obejmowały zwłaszcza slawistykę, indoeuropeistykę, językoznawstwo ogólne), w swoich pracach język polski uwzględniali, zwłaszcza jako kontekst przy badaniach slawistycznych, często o charakterze porównawczym. Natomiast Dobrzycki w swoich naukowych poczynaniach łączył dwie dyscypliny: historię literatury polskiej i językoznawstwo polonistyczne.

Pierwszy z wymienionych, Mikołaj Rudnicki (1881-1978), studiował przedmioty językoznawcze, głównie indoeuropeistykę i filologię słowiańską, na UJ pod kierun- 
kiem jednego z najwybitniejszych ówczesnych badaczy - Jana Rozwadowskiego. Pod jego też naukową opieką studia uwieńczył w 1908 r. doktoratem na podstawie rozprawy Asymilacje głosek sasiednich w środku wyrazów w językach indoeuropejskich, romańskich $i$ słowiańskich ${ }^{1}$. Studia lingwistyczne pogłębiał w Kopenhadze, Sztokholmie, Uppsali, Wiedniu, Berlinie i Pradze, epizodycznie też w Paryżu i we Florencji. Wkrótce, w roku akademickim 1911/1912, habilitował się na UJ na podstawie pracy z zakresu językoznawstwa indoeuropejskiego i ogólnego Studia psychofonetyczne. I. Asymilacja. Gruntowne wykształcenie zdobyte w kraju i za granicą oraz dokonania naukowe usytuowały Rudnickiego wśród największych lingwistów już pierwszych dziesięcioleci XX w. Jak ocenia Bogdan Walczak: „Mało kto z ówczesnych (a i późniejszych) polskich językoznawców mógł się poszczycić podobnym wykształceniem” (Walczak 2014: 13). Początkowo Rudnicki podjął pracę w C.K. Seminarium Nauczycielskim Męskim w Krakowie, a także jako docent prywatny wykładał przedmioty językoznawcze na UJ. Działał też aktywnie naukowo. Wiele publikował w czasopismach „Język Polski”, „Poradnik Językowy”, „Rocznik Slawistyczny”. Poszukujący kadr uniwersytet w Poznaniu już w 1919 r. zaproponował Rudnickiemu objęcie na tworzącej się uczelni katedry językoznawstwa indoeuropejskiego i ogólnego. Rudnicki propozycję przyjął, przybył do Poznania i włączył się w działania organizujące życie naukowe Wszechnicy Piastowskiej ${ }^{2}$. Z Poznaniem i jego uniwersytetem związał się już na stałe. Zyskała więc poznańska uczelnia wybitnego badacza, lingwistę specjalizującego się $\mathrm{w}$ problematyce z zakresu językoznawstwa indoeuropejskiego i ogólnego oraz w slawistyce, mającego już znaczny dorobek naukowy i doświadczenie także w badaniach szczególowych, zwłaszcza onomastycznych i dialektologicznych (np. w 1915 r. w Krakowie opublikował pracę Puck i jego gniazdo etymologiczne, a wcześniej, w 1913 r., obszerne studium Przyczynki do gramatyki i słownika narzecza słowińskiego).

Po przybyciu do Poznania Rudnicki znacznie ograniczył dociekania teoretyczne, choć ich całkowicie ze swoich badań nie wyeliminował. W okresie poznańskim bowiem powstał ważny artykuł Język jako zjawisko pamięciowe. Prawo identyfikacji zjawisk niedostatecznie różnych (1927), w którym wyłożył metodę objaśniania zjawisk językowych, mającą u podstaw psychologicznie warunkowane prawo identyfikowania zjawisk niedostatecznie zróżnicowanych. Metodę tę zastosował z powodzeniem do objaśnienia zjawiska mazurzenia w języku polskim. Badania Rudnickiego w tym okresie koncentrowały się jednak głównie wokół zagadnień dotyczących Słowiańszczyzny, zwłaszcza jej odłamu zachodniego. W 1921 r. założył poświęcone tym problemom czasopismo „Slavia Occidentalis” i był jego redaktorem naczelnym do 1950 r. $^{3}$

1 Notki bibliograficzne przywoływanych prac Rudnickiego zob. w: Zabrocki 1960.

2 Pierwszą nazwą poznańskiej uczelni była „Wszechnica Piastowska”. Nazwa ta obowiązywała przez pierwszy rok działalności uczelni, następnie przemianowano ją na Uniwersytet Poznański, a w 1955 r. na Uniwersytet im. Adama Mickiewicza w Poznaniu.

3 Czasopismo było organem Instytutu Zachodniosłowiańskiego założonego wspólnie z T. Lehrem-Spławińskim przy Uniwersytecie Poznańskim. 
Zachodniej Słowiańszczyźnie, w tym językowi polskiemu, poświęcił wiele studiów, zwłaszcza onomastycznych (toponimicznych i hydronimicznych), wzbogaconych wywodami etymologicznymi, jak Nazwa miasta Gdańska (1921), w którym dowodził "polsko-kaszubskiego” pochodzenia nazwy, czy Niektóre nazwy miejscowości na -ądz (1925). W „Slavii Occidentalis” ukazało się też wiele innych artykułów Rudnickiego z zakresu nazw hydronimicznych z polskiego obszaru językowego, jak: Gopło i Pelso (1925), Nazwa rzeki Bug (1927) czy Odra i Drawa (1927). Wkrótce, w 1929 r., w „Pamiętniku Instytutu Bałtyckiego. Seria Balticum” opublikował dwa obszerne syntetyczne szkice: Nazwy geograficzne Pomorza Wschodniego (Gdańskiego) i Charakterystyka językowa Pomorza. Zainteresowania Słowiańszczyzną zachodnią zaowocowały też onomastycznym studium Nazwy Słowian (zachodnich) w dokumentach niemieckich (1928). Zainteresowania Słowiańszczyzną nie ograniczał Rudnicki do zagadnień onomastycznych, choć to głównie one skłoniły go do zaakceptowania wysuniętej przez J. Kostrzewskiego tezy o pierwotnej lokalizacji Słowian między Łabą i Wisłą (Rzetelska-Feleszko 1987: 56). Ważne miejsce w jego badaniach zajmowała też fonetyka słowiańska. Już w 1921 r. ukazał się w „Slavii Occidentalis” duży artykuł zatytułowany Metateza w językach zachodniosłowiańskich, przede wszystkim lechickich, a także Ekskurs o ogólnosłowiańskiej przestawce płynnych.

Drugim wybitnym lingwistą, który związał się z uniwersytetem w Poznaniu od początku jego działalności (choć tylko na trzy lata), był Tadeusz Lehr-Spławiński (1891-1965), absolwent UJ, gdzie pod kierunkiem Jana Łosia, Jana Rozwadowskiego i Kazimierza Nitscha studiował filologię słowiańską i klasyczną oraz historię literatury polskiej. Wiedzę pogłębiał na uniwersytecie w Wiedniu. W $1913 \mathrm{r}$. na UJ uzyskał doktorat na podstawie pracy Studia nad akcentem pomorskim ${ }^{4}$, a w 1917 r. habilitację, której podstawą była rozprawa Ze studiów nad akcentem słowiańskim. Po kilkuletnim epizodzie pracy nauczycielskiej w Zakopanem i Krakowie w $1918 \mathrm{r}$. podjął prace na UJ, ale już w 1919 r. przeniósł się na nowo utworzony uniwersytet w Poznaniu, gdzie objął kierownictwo katedry filologii słowiańskiej. Jak pokazują tytuły jego prac z wczesnego okresu - krakowskiego i następnie poznańskiego - specjalizował się w fonetyce słowiańskiej, szczególnie w zagadnieniach akcentu i w różnych zagadnieniach z zakresu języka połabskiego. Z prac polonistycznych przed przybyciem do Poznania opublikował jeden artykuł o polszczyźnie Kresów Wschodnich: O mowie Polaków w Galicji Wschodniej (1914). I choć głównym obszarem jego zainteresowań nie był wówczas język polski, właśnie z tego przedmiotu, razem z Dobrzyckim i Rudnickim, prowadził zajęcia dla studentów UP aż do roku 1922, czyli do momentu powołania katedry języka polskiego (Maciejewski 2018: 56). W krótkim okresie poznańskim, w latach 1919-1922, opublikował kilka artykułów zróżnicowanych tematycznie. Rok 1920 przyniósł obszerne studium Zapożyczenia dolno-niemieckie w języku połabskim, w roku 1921 opublikował kilka prac dotyczących połabszczyzny:

4 Notki bibliograficzne przywoływanych prac Lehra-Spławińskiego zob. w: Siudut 1951. 
O działaniu analogii w koniugacji połabskiej, Z deklinacji połabskiej oraz obszerny artykuł o charakterze porównawczym, włączający w obszar zainteresowań również język polski: Mowa dawnych Połabian w stosunku do grupy językowej pomorsko-polskiej. W roku 1922 napisał, we współautorstwie z Józefem Łęgowskim, artykuł Szczątki języka dawnych stowiańskich mieszkańców Rugii ${ }^{5}, \mathrm{w}$ którym autorzy poszukiwali w języku dawnych mieszkańców tej największej wyspy Pomorza, administracyjnie należącej do Niemiec, śladów słowiańskich. W tym samym roku wydał też, nakładem Koła Polonistów Uniwersytetu Poznańskiego, bardzo przydatny na studiach slawistycznych i polonistycznych podręcznik Zarys gramatyki języka staro-cerkiewno-słowiańskiego ${ }^{6}$. Kierunki badań zapoczątkowane na UP rozwijał Lehr-Spławiński po odejściu z Poznania, we Lwowie i Krakowie (Kuraszkiewicz 1973: 504). Jak ocenia Zdzisław Stieber: „Trzyletni zaledwie pobyt młodego uczonego w Poznaniu wystarczył do nawiązania z tym ośrodkiem naukowym niezwykle silnych kontaktów" (Stieber 1962: 1), które przetrwały wiele lat.

Trzecim uczonym, współtwórcą poznańskiego językoznawstwa polonistycznego, jest Stanisław Dobrzycki (1875-1931), związany z UP od jego powstania do 1931 r., absolwent Wydziału Filozoficznego na UJ, na którym studiował literaturę, filologię klasyczną, filozofię, językoznawstwo. W zakresie językoznawstwa jego mistrzami byli Lucjan Malinowski, twórca polskiej dialektologii, i Jan Baudouin de Courtenay, jeden z najwybitniejszych polskich językoznawców, twórca kazańskiej szkoły językoznawczej. Ze studiów na krakowskiej uczelni wyniósł Dobrzycki „pierwszorzędne przygotowanie w zakresie językoznawstwa polskiego, słowiańskiego i indoeuropejskiego" (Prażmowski 1963: 18). Studia slawistyczne pogłębiał w Pradze. Po powrocie do Krakowa na podstawie rozprawy O mowie ludowej we wsi Krzęcinie ${ }^{7}$ w 1898 r. uzyskał doktorat, nadany przez Wydział Filozoficzny UJ. Jak sugeruje Mieczysław Prażmowski, rozprawa doktorska Dobrzyckiego była swoistym hołdem złożonym przez autora jego mistrzowi, L. Malinowskiemu. On też zainspirował młodego uczonego do badań dialektologicznych (ibid.: 15). W 1901 r. Dobrzycki objął po J. Kallenbachu stanowisko profesora literatur i języków słowiańskich na uniwersytecie we Fryburgu. Pozostał tam do 1919 r., choć już wcześniej myślał o powrocie do kraju i o objęciu katedry języka polskiego w Uniwersytecie Warszawskim. W liście do Teodora Wierzbowskiego pisał:

5 Józef Łęgowski (1852-1930), historyk, etnograf, językoznawca, nauczyciel, absolwent uniwersytetów we Wrocławiu i w Królewcu, gdzie studiował historię, geografię i języki klasyczne, doktorat uzyskał w zakresie filozofii. Aż do przejścia na emeryturę pracował jako profesor gimnazjalny w Wejherowie, w Arnsbergu w Westfalii, w Wągrowcu i Poznaniu (Bieńkowski 1973: 353-356). Poza wymienionym artykułem w swoim dorobku ma m.in. takie prace, jak: Kaszuby i Kociewie: język, zwyczaje przesądy, podania, zagadki i pieśni ludowe w północnej części Prus Zachodnich (Poznań 1892) i Ukazanie się Słowian lechickich nad Bałtykiem („Slavia Occidentalis” 1926, 5, s. 247-280).

6 Zarys gramatyki... w kolejnych latach był wielokrotnie wznawiany.

7 Notki bibliograficzne przywoływanych prac Dobrzyckiego zob. w: Prażmowski 1963: 282-313. 
Studiom gramatycznym poświęcałem się od początku moich lat uniwersyteckich i w ostatnich czasach więcej pracowałem nad literaturą, do czego mnie zresztą po części zmusił Fryburg, bo jakkolwiek wykładałem tu gramatykę, to jednak głównie trzeba było zwrócić uwagę na literaturę. Związku jednakże z lingwistyką nie straciłem (cyt. za: ibid.: 27).

Lata pracy we Fryburgu, jak sam odnotował w cytowanym wyżej liście, nie oderwały go od badań językoznawczych. Okres pracy przed przybyciem do Poznania w 1919 r. dzielił między badania literaturoznawcze i językoznawcze. W zakresie badań lingwistycznych skupiał się przede wszystkim na dialektologii i w nieco mniejszym zakresie na historii języka polskiego (np. O tak zwanym mazurowaniu $w$ języku polskim czy obszerne studium historycznojęzykowe Notatki do dziejów języka polskiego: I. Kilka spostrzeżeń nad językiem Mickiewicza, II. Z dziejów języka krytyki literackiej). Z takimi też kompetencjami naukowymi przybył do nowo utworzonego uniwersytetu w Poznaniu, gdzie objął katedrę historii literatury polskiej (choć proponowano mu katedrę języka polskiego). Tym samym swoje badania związał z literaturoznawstwem, językoznawstwo odsuwając na dalszy plan. Zresztą, jak ocenia Prażmowski: „Jeśli chodzi o twórczość naukową Dobrzyckiego w czasie pobytu w Poznaniu, to jest ona i jakościowo, i ilościowo skromniejsza niż twórczość w okresie fryburskim" (ibid.: 53). Z zakresu języka polskiego opublikował w 1922 r. obszerny artykuł onomastyczny Próba objaśnienia kilku nazw geograficznych wielkopolskich, w którym skupił się na objaśnieniu dwóch nazw: rzeki Debrzyca i miejscowości Urzut. Rok później opublikował artykuł O piękności języka, zaś w 1931 r. ukazał się jego ostatni językoznawczy tekst - Kultura języka w wieku XVI, w którym podkreślił brak prac o języku renesansowych pisarzy bądź zbytnią ich ogólnikowość. Artykuł był pokłosiem wystąpienia na Zjeździe Naukowym im. Jana Kochanowskiego w Krakowie: Kultura i artyzm języka w XVI wieku. Biograf życia i dokonań naukowych Dobrzyckiego, M. Prażmowski, podsumowuje:

Referat był ambitnym początkiem, wskazywał zaistniałe pustki w badaniach, wytyczał najogólniej ich drogi, pokazywał metody i plany przyszłych prac, mobilizował do nich, przynosił również szereg fundamentalnych myśli i stwierdzeń, pobudzał do rewizji metod w badaniach językowych (ibid.: 135).

Od początku istnienia uniwersytetu w Poznaniu związany z nim był również Stanisław Kozierowski (1874-1949), członek Komisji Organizacyjnej Uniwersytetu Polskiego w Poznaniu, ksiądz po studiach teologicznych i filozoficznych odbytych w seminariach duchownych Poznania i Gniezna, związany z probostwami na terenie Wielkopolski, samouk w zakresie językoznawstwa, od 1919 do 1939 r. pracujący na Uniwersytecie Poznańskim przy jednoczesnym pełnieniu posługi kapłańskiej (jako proboszcz) w podpoznańskim Skórzewie, następnie w Winnej Górze koło Środy Wielkopolskiej. Zainteresowania naukowe Kozierowskiego ujawniły się już w pierwszych latach XX w. i koncentrowały się wokół genealogii i heraldyki, 
natomiast jego pierwsze prace językoznawcze (onomastyczne) przypadają na drugie dziesięciolecie XX w. Już w 1914 r. zaczął publikować wielotomowe dzieło Badania nazw topograficznych ${ }^{8}$, wydawane w Poznaniu przez Poznańskie Towarzystwo Przyjaciół Nauk aż do 1939. W kolejnych tomach serii zgromadził ogromny materiał onimiczny historyczny i współczesny z właściwej Wielkopolski, ale też granicę tę przekraczał ${ }^{9}$. Materiał pozyskany ze źródeł rękopiśmiennych i drukowanych, mimo zdarzających się uchybień w odczytaniu nazw czy powtarzaniu błędów za źródłami, miał wartość niepodważalną. Nieco gorzej radził sobie Kozierowski z rekonstrukcjami pierwotnych postaci nazw i z ich etymologizowaniem, ale u autora bez wykształcenia językoznawczego dziwić to nie może. Mankamenty te dostrzegali już ówcześni lingwiści, jak J. Rozwadowski. W ocenie B. Walczaka:

Wartość dzieła kompensuje wszelkie braki, a sam materiał, imponujący pod względem ilościowym, miał wartość bezcenną i przez długie dziesięciolecia służył onomastom i historykom języka polskiego. Ogrom pracy przyniósł więc wyniki na miarę włożonego trudu (Kijas, Walczak 2010: 30).

Wydawaniu tego monumentalnego dzieła towarzyszyły też inne prace Kozierowskiego, w których czynnik językoznawczy (onomastyczny) odgrywał zasadniczą rolę jako argument w wywodach historycznych dotyczących pierwotnego osadnictwa na obszarze Wielkopolski i ziem przyległych, jak np.: Pierwotne osiedlenie ziemi gnieźnieńskiej wraz z Pałukami w świetle nazw geograficznych i charakterystycznych imion rycerskich (1925), Pierwotne osiedlenie dorzecza Warty od Koła do Ujścia w świetle nazw geograficznych (1926), Pierwotne osiedlenie pogranicza wielkopolsko-śląskiego między Obrą i Odra a Wartą i Bobrem w świetle nazw geograficznych (1928). Pisał też mniejsze rozmiarami prace, w których zagadnienia onomastyczne były podstawą wywodu, jak np. Niektóre nazwy geograficzne na dawnym pograniczu wielkopolsko-pomorskim (1928).

W językoznawstwie polonistycznym Kozierowski zapisał się jako onomasta, zwłaszcza jako eksplorator nazw miejscowych, wodnych, heraldycznych. Jego ogromny dorobek onomastyczny B. Walczak podsumowuje:

[...] mimo niedostatków interpretacyjnych, wypływających z braku solidnego i systematycznego przygotowania językoznawczego, prace ks. Kozierowskiego miały przez dziesięciolecia, a w części mają do dziś, ogromne znaczenie dla polskiej onomastyki jako zbiory materiałów. Można powiedzieć, że stanowiły (a w części stanowią do dziś) jeden z fundamentów materiałowych tej dyscypliny naukowej (ibid.: 37 ).

8 Bibliografia dorobku naukowego Kozierowskiego, jak dotąd, nie została opracowana.

9 Jak podkreślił Władysław Kuraszkiewicz: „Żadna z dzielnic Polski nie doczekała się podobnego opracowania toponomastycznego jak Wielkopolska w Badaniach... Kozierowskiego" (Kuraszkiewicz 1973: 510). 
W końcu 1921 r. ze Lwowa do Poznania przeniósł się Henryk Ułaszyn (1874-1956), który studia uniwersyteckie odbył wpierw w Kijowie, następnie w Krakowie na Wydziale Filozoficznym UJ, gdzie zetknął się z Baudouinem de Courtenay, który wywarł pewnie największy wpływ na młodego uczonego (Skarżyński, Walczak 2009: 19). Jak pisze Mirosław Skarżyński:

Wpływ Baudouina na Ułaszyna był wielki i zasadniczy nie tylko w sprawach naukowych, ale też w ukształtowaniu się jego światopoglądu. [...] Finałem całożyciowego uwielbienia dla Baudouina było życzenie Ułaszyna, by pochowano go obok swego mistrza, co też się i stało (ibid.: 12).

Przybywając do Poznania, Ułaszyn był już doświadczonym badaczem i dydaktykiem. Miał za sobą epizod pracy w Lipsku, w czasie I wojny światowej wykładał na Wyższych Polskich Kursach Naukowych w Kijowie i wreszcie przez niespełna dwa lata pracował na Uniwersytecie Jana Kazimierza we Lwowie, gdzie prowadził katedrę języka polskiego po Kazimierzu Nitschu, który przeniósł się do Krakowa. W 1904 r. uzyskał doktorat na podstawie pracy z zakresu fonetyki historycznej języka polskiego: Über die Entpalatalisierung der ursl. e-Laute im Polonischen (wydanej rok później, w 1905, w Lipsku) ${ }^{10}$. Ważne prace poświęcił też słowotwórstwu. Na pierwszy plan wysuwa się obszerny artykuł Słowotwórstwo (1915), będący pierwszą na gruncie polskim opisową syntezą tego działu języka.

Po przyjeździe do Poznania Ułaszyn objął po Lehrze-Spławińskim katedrę filologii słowiańskiej, natomiast jego prace koncentrowały się na zagadnieniach historycznej i współczesnej polszczyzny. Wymiar slawistyczny miał przygotowany przez niego podręcznik Język starocerkiewnosłowiański. Zarys gramatyki. Ćwiczenia. Teksty. Stownik z 1928 r. Natomiast z zakresu historycznej fonetyki i fonologii języka polskiego opublikował w tym samym roku kilka artykułów, jak np. O pewnej kategorii wtórnej nazalizacji w języku polskim. Wiele uwagi w swoich badaniach, podobnie jak w okresie wcześniejszym, poświęcał słowotwórstwu. Najważniejszą jego pracą słowotwórczą z późnego okresu poznańskiego, z 1931 r., jest z pewnością artykuł Laut, Phonema, Morphonema, wprowadzający do nauki termin morfonem(a). Pisał też drobniejsze prace z tego działu nauki o języku, np. W sprawie przyrostków -'ec $i$-'ca. Pro domo mea (1925). Kontynuował również badania nad socjolektami. Przez wiele lat zajmował go socjolekt środowisk złodziejskich. W interesującym nas tu okresie efektem tych badań była publikacja z 1927 r. O polskim języku złodziejskim. W okresie międzywojnia Ułaszyna interesowały także zagadnienia kultury języka, ujawnione choćby w pracach Jeszcze o spaźniać się (1923) czy O poprawności języka urzędowego (1930), ale podejmował też badania nad językiem osobniczym, czego wyrazem jest obszerne studium Żeromski a język polski z 1926 r. Do tego dochodzą drobne prace leksykograficzne, jak: Żubrówka (1927), Suhak - sumak (1928) czy Perskie oko (1929).

10 Notki bibliograficzne przywoływanych prac Ułaszyna zob. w: Ułaszyn 1955. 
W styczniu 1922 r. przybył z Krakowa Edward Klich (1878-1939), który z Poznaniem związał już resztę swego życia. Klich to wychowanek UJ, uczeń Malinowskiego, Baudouina de Courtenay, Rozwadowskiego i Łosia. Po studiach podjął pracę nauczyciela gimnazjalnego. Wówczas też zgromadził materiał i przygotował pracę Narzecze wsi Borki Nizińskie (1919) ${ }^{11}$, która stała się podstawą przewodu doktorskiego. W 1922 r., po nieudanych próbach utworzenia w 1919 r. katedry języka polskiego na UP (nie było odpowiedniego kandydata do jej poprowadzenia), Klichowi zaproponowano etat zastępcy profesora (nie miał bowiem jeszcze habilitacji) i funkcję kierownika katedry języka polskiego. Klich przyjął zaproszenie i objął zaproponowane stanowisko, inicjując tym samym pracę nowej katedry na UP.

Przybywając do Poznania, Klich miał już doświadczenie w prowadzeniu badań dialektologicznych, co z pewnością było efektem słuchania wykładów akademickich L. Malinowskiego. Po przybyciu do Poznania, ze względu na słabe zdrowie, badań dialektologicznych w terenie już nie prowadził (Walczak 2011: 15). Jednak od dialektologii nie odszedł. Podjął się przygotowania do druku i opracowania materiałów gwarowych, które zgromadzili inni eksploratorzy. I tak np. w 1930 r. do druku przygotował i wstępem opatrzył publikację Gwara ślemieńska. 1. Słownik autorstwa Stefana Ramułta. Badania własne natomiast przeniósł na inne pola. Najbliższe dialektologii były jego studia nad językiem Cyganów osiadłych w Polsce, czego efektem jest praca Wpływ języka polskiego na dialekty Cyganów polskich (1927). Zainteresowania Klicha językiem Cyganów zaowocowały też obszernym artykułem Cygańszczyzna $w$ „Chacie za wsia” Kraszewskiego (1931), który nie tyle pokazuje właściwości tego języka, ile warsztat pisarski Kraszewskiego, który wprowadził tę odmianę języka w celach stylizacyjnych, czerpiąc wyrazy cygańskie nie z obserwacji miejscowych Cyganów, ale korzystając, jak dowiódł Klich, z francuskiego słowniczka dialektu Cyganów baskijskich. „Tak więc - pisze B. Walczak - w jednej z najpopularniejszych powieści Kraszewskiego Cyganie polescy przemawiają językiem stylizowanym na dialekt Cyganów baskijskich" (ibid.: 17).

Z pracą o stylizacji cygańszczyzny w Chacie za wsia w relacji pozostają artykuły Klicha dotyczące utworów artystycznych również innych autorów i stosowanych przez nich zabiegów stylizacyjnych ${ }^{12}$. Są to jednak prace już z końca lat 30. XX w., a więc wykraczające poza ramy czasowe artykułu.

W okresie poznańskim Klich poświęcił wiele uwagi historii języka polskiego, zwłaszcza historii słownictwa. Największym jego osiągnięciem w tym zakresie bez wątpienia jest monografia Polska terminologia chrześcijańska (1927), która też była podstawą jego przewodu habilitacyjnego. Główną myślą pracy było pochodzenie polskiej terminologii chrześcijańskiej. Zgodnie z ustaleniami Klicha większość terminów przywołanych w pracy wykazuje czeskie pochodzenie lub czeskie

11 Bibliografia dorobku naukowego Klicha, jak dotąd, nie została opracowana.

12 Np. Dialektyczne zabarwienie języka pism Julii Woykowskiej (Klich 1939). 
pośrednictwo w procesie przyjmowania zapożyczenia przez język polski. Ważnym zagadnieniem sytuującym się $\mathrm{w}$ tym nurcie badawczym, a więc leksykologii historycznej, była kwestia wpływów ruskich w polszczyźnie, którym Klich poświęcił kilka prac. Najobszerniejsze powstały na podstawie Słownika etymologicznego Aleksandra Brücknera (Klich 1926, 1929), w których, wbrew autorowi słownika, słusznie podkreślał rangę tych wpływów w języku polskim.

W twórczości naukowej Klicha znalazły się też prace dotyczące różnych zagadnień współczesnego języka: odmiany mówionej, np. O nowotworze wysokożem wylazł itp. (zam. wysokom wylazł...) (1934), zwłaszcza zaś składni, np. Dwa przypadki kontaminacji syntaktycznej w języku polskim (1934), czy też poprawności językowej, jak: Każdy nie... (1929).

Przedstawieni badacze, językoznawcy z wykształcenia lub z pasji (jak Kozierowski), to pierwsze pokolenie uczonych, którzy zajmowali się naukowo różnymi problemami lingwistycznymi na UP, to indoeuropeiści i slawiści, którzy w swoich badaniach uwzględniali też język polski, tworząc w ten sposób podwaliny językoznawstwa polonistycznego na młodej poznańskiej uczelni. Początkowo skupiali się głównie na onomastyce i dialektologii, w mniejszym zakresie na innych działach języka. Sytuacja zmieniła się, gdy wraz z przybyciem w 1922 r. Klicha i parę miesięcy wcześniej Ułaszyna, koncentrujących się przede wszystkim na języku polskim, obszar badań został znacznie poszerzony o takie działy, jak historia języka polskiego, współczesna polszczyzna ogólna i jej odmiany artystyczne i socjalne, leksykologia, kultura języka. Do głosu zaczyna też dochodzić nowe pokolenie językoznawców - wychowankowie UP. Nie tylko podejmują oni, ale też znacznie poszerzają problematykę, która już wcześniej była obecna w pracy ich mistrzów. Tu przede wszystkim wspomnieć trzeba o badaniach dialektologicznych, które w Poznaniu znacznie się rozwinęły za sprawą Adama Tomaszewskiego (1895-1945), który zajął się gwarami wielkopolski$\mathrm{mi}^{13}$. Choć etatowo z uniwersytetem związany nie był, to jednak z uczelnią był mocno związany naukowo. Tu się doktoryzował i habilitował. Szczególnie zasłynął jako eksplorator materiału gwarowego, którego nie zdążył w pełni wykorzystać w swoich pracach twórczych, jednakże jest autorem wielu publikacji tak drobniejszych, jak i książkowych, np. Gwara Łopienna i okolicy w północnej Wielkopolsce (1930) ${ }^{14}$ czy Mowa ludu wielkopolskiego (1934). Polonistykę w Poznaniu studiował też, mając już wówczas święcenia kapłańskie (otrzymał je w 1915 r.), ks. Piotr Gołąb (1888-1943). Był czynnym duchownym, $z$ uniwersytetem zawodowo się nie związał, ale kilka prac językoznawczych opublikował. Do ważniejszych należą: slawistyczno-polonistyczna Połabskie rüz-||vüz- a polskie roz-||uoz- (1921), onomastyczne O kilku nazwach topo-

13 Duży wpływ na Adama Tomaszewskiego wywarł Kazimierz Nitsch, który przez jeden trymestr był wykładowcą na UP.

14 Bibliografie dorobku naukowego Tomaszewskiego i w dalszej części artykułu wspomnianych Piotra Gołąba i Władysława Pniewskiego, jak dotąd, nie zostały opracowane. 
graficznych na Śląsku Opolskim (1938) i Małopiana czy Mała Panew (1939). Również tylko okresowo z Uniwersytetem Poznańskim związany był Władysław Pniewski (1893-1940), Wielkopolanin z pochodzenia, który studiował wpierw na Uniwersytecie Jagiellońskim, następnie we Wrocławiu, w 1919 r. przeniósł się na nowo otwarty Uniwersytet Poznański, gdzie ukończył studia polonistyczne, a w 1925 r. uzyskał tu doktorat na podstawie rozprawy z zakresu dialektologii Narzecze wsi Zgorzelca. Jednak już w 1924 r. podjął pracę jako nauczyciel języka polskiego w Gdańsku i po uzyskaniu doktoratu badań językoznawczych nie kontynuował (GSB).

Spojrzenie na początkowy okres rozwoju językoznawstwa polonistycznego na UP przez pryzmat uczonych, którzy budowali tę dyscyplinę w młodej uczelni, wspiera ocenę wyrażoną przez Zygmunta Zagórskiego, który powiedział, że uczeni ci: „[...] przyczynili się do utworzenia na naszym Uniwersytecie silnego jak na ówczesne czasy ośrodka badań językoznawczych" (Zagórski 2011: 13). Byli to przybysze z zewnątrz - wpierw z Uniwersytetu Jagiellońskiego, później też lwowskiego. Przyjechali do Poznania $\mathrm{z}$ ugruntowaną już pozycją w nauce, ze znaczącym dorobkiem w zakresie slawistyki, indoeuropeistyki, językoznawstwa ogólnego. W Poznaniu badania kontynuowali, ale też je rozszerzali, dołączając, wcześniej słabiej zaznaczone, badania polonistyczne. Ranga lingwistyki polonistycznej na UP znacznie wzrosła wraz z przybyciem H. Ułaszyna, później E. Klicha i ukonstytuowaniem się katedry języka polskiego. W ten sposób już od pierwszych lat działalności poznańskiej uczelni zaistniało na niej językoznawstwo polonistyczne, w kolejnych latach rozwijane i wzmacniane.

\section{Literatura}

Bieńkowski W., 1973, Łęgowski Józef, [w:] Polski słownik biograficzny, t. XVIII, Wrocław, s. $353-356$.

GSB: Gostyński słownik biograficzny, [on-line:] www.muzeum.gostyn.pl/GOSTYŃSKI\%2O SŁOWNIK\%2OBIOGRAFICZNY.

KAnIEwska B., 2018, O początkach i nie tylko, [w:] B. Judkowiak, S. Wysłouch, S. Karolak, A. Piotrowicz (red.), Stulecie poznańskiej polonistyki (1919-2019), t. 1: Okres międzywojenny i lata okupacji, Poznań, s. 11-18.

KiJAs A., WalCZAK B., 2010, Ksiądz Stanisław Kozierowski - onomasta i historyk, [w:] S. Kozierowski, Studia onomastyczno-historyczne, wstęp i dobór tekstów A. Kijas, B. Walczak, „Klasycy Nauki Poznańskiej”, t. 44, Poznań, s. 9-44.

Kuraszkiewicz W., 1973, Językoznawstwo polskie i słowiańskie na Uniwersytecie Poznańskim (1919-1969), [w:] G. Labuda (red.), Nauka w Wielkopolsce: przeszłość i teraźniejszość: studia i materialy: praca zbiorowa, Poznań, s. 499-540.

Łukomski G., 2019, Uniwersytet im. Adama Mickiewicza w Poznaniu. Pięć wieków tradycji, [on-line:] https://amu.edu.pl/__data/assets/pdf_file/o015/50523/Uniwersytet-im.-Adama -Mickiewicza-w-Poznaniu-Piec-wiekow-tradycji.pdf. 
Maciejewski J., 2018, Uniwersyteckie tradycje filologii polskiej w Poznaniu, [w:] B. Judkowiak, S. Wysłouch, S. Karolak, A. Piotrowicz (red.), Stulecie poznańskiej polonistyki (1919-2019), t. 1: Okres międzywojenny i lata okupacji, Poznań, s. 21-61.

Prażmowski M., 1963, Działalność naukowa i pedagogiczna Stanisława Dobrzyckiego, Poznań.

Rzetelska-Feleszko E., 1987, Językoznawstwo zachodniosłowiańskie w Polsce: przewodnik, Warszawa.

Siudut A., 1951, Bibliografia prac naukowych Tadeusza Lehra-Spławińskiego 1911-1950, „Przegląd Zachodni” nr 7-8, s. 610-624.

SkarżyŃski M., WAlczak B., 2009, Profesor Henryk Ułaszyn (1874-1956), [w:] H. Ułaszyn, Studia onomastyczne i socjolingwistyczne, wstęp i dobór tekstów M. Skarżyński, B. Walczak, „Klasycy Nauki Poznańskiej”, t. 41, Poznań, s. 9-37.

STIEber Z., 1962, Tadeusz Lehr-Spławiński jako slawista i polonista (w pięćdziesięciolecie twórczości naukowej), „Język Polski” XLII, s. 1-7.

[UŁAszyn H.], 1955, Bibliografia prac, artykułów i notatek Henryka Ułaszyna opublikowanych $w$ latach 1898-1954 (zestawił autor), „Rozprawy Komisji Językowej Łódzkiego Towarzystwa Naukowego" II, s. 13-50.

URBAŃcZY K S., 1993, Dwieście lat polskiego językoznawstwa (1751-1950), „Rozprawy Wydziału Filologicznego PAU” 6o, Kraków.

WalczaK B., 2011, Edward Klich - życie i twórczość naukowa, [w:] E. Klich, O polszczyźnie i cygańszczyźnie, wstęp i dobór tekstów B. Walczak, „Klasycy Nauki Poznańskiej”, t. 61, Poznań, s. 9-22.

WAlCZAK B., 2014, Mikołaj Rudnicki - życie i dzieło, [w:] M. Rudnicki, Językoznawstwo ogólne - Paleoslawistyka - Onomastyka - Historia języka - Posnaniana, wstęp i dobór tekstów B. Walczak, „Klasycy Nauki Poznańskiej”, t. 69, s. 11-33.

Zаввоскі L., 1960, Bibliografia prac, artykułów i recenzji naukowych Mikołaja Rudnickiego do końca r. 1959, „Slavia Occidentalis” 20, s. 19-27.

ZAGórski Z., 2011, Językoznawstwo polskie na Uniwersytecie im. Adama Mickiewicza w latach 1919-2009 (w zarysie), „Poznańskie Spotkania Językoznawcze. Zeszyt Specjalny”, Poznań.

\section{The Origins of Polish Language Studies at Poznań University Summary}

Linguistic studies on the Polish language and literature were first conducted at the Faculty of Philosophy of Poznań University (established in 1919). Studies on literary theory were pursued in the Department of History of Polish Literature, whereas linguistic studies in the Department of Slavic Philology and Indo-European Linguistics. Initially, these studies were supervised by scholars who came from the Jagiellonian University in Cracow: Mikołaj Rudnicki and Tadeusz Lehr-Spławiński, as well as Stanisław Dobrzycki who was active in two fields, theory of literature and linguistics. It was only in 1922 that the Department of the Polish Language was established thanks to the efforts of Edward Klich, who also came from Cracow. At first, Polish language studies at Poznań University concentrated on two fields: onomastics (with components of etymology), and dialectology. More comprehensive research was conducted since the establishment of the Department of the Polish Language which was joined by a new generation of linguists, including graduates of Poznań University. 